\author{
AMERICAN JOURNAL OF FOOD AND NUTRITION \\ Print: ISSN 2157-0167, Online: ISSN 2157-1317, doi:10.5251/ajfn.2012.2.3.55.57 \\ (c) 2012, ScienceHuß, http://www.scihub.org/AJFN
}

\title{
Chemical evaluation of food value of groundnut (Arachi hypogaea) seeds
}

\author{
${ }^{*}$ Ayoola, P.B ${ }^{1}$., Adeyeye, $A^{1}$ and Onawumi, $0.0^{2}$ \\ ${ }^{1}$ Department of Science Laboratory Technology, Ladoke Akintola University of \\ Technology,P.M.B.4000, Ogbomoso, Oyo State, Nigeria. \\ ${ }^{2}$ Department of pure and Applied Chemistry, Ladoke Akintola University of \\ Technology,P.M.B.4000,Ogbomoso,Oyo State, Nigeria.
}

\begin{abstract}
The human and animal body is made and maintained from the food taken in together with Oxygen breathes in from the air. The food consists of carbohydrates, proteins, Fats, Mineral matter, Vitamins and water, which are collectively known as nutrients (food substances). The proximate and mineral analysis of groundnut (Arachis hypogeal) seeds were carried out and were determined on dry weight basis. The results showed that the groundnut seeds (raw ,sundried and roasted) contain moisture content of $7.40 \%, 3.40 \%, 1.07 \%$; ash content of $1.48 \%, 1.38 \%, 1.41 \%$; Crude protein of $24.70 \%, 21.80 \%, 18.40 \%$; Crude fat of $46.10 \%, 43.80 \%, 40.60 \%$; Crude fibre of $2.83 \%, 2.43 \%, 2.41 \%$; Carbohydrate of $17.41 \%, 27.19 \%, 36.11 \%$; respectively. Minerals included; Sodium $(0.71 \%, 0.69 \%, 0.57 \%)$,phosphorus $(0.68 \%, 0.65 \%, 0.69 \%)$,potassium $(0.47 \%, 0.51 \%, 0.55 \%)$, zinc $(0.44 \%, 0.42 \%, 0.50 \%)$, iron $(0.40 \%, 0.47 \%, 0.43 \%)$. There was a general decrease in the proximate composition after exposure to different heating methods but there was variation in the mineral contents of the seeds after heating. Based on the values obtained, the possible use of Groundnut Seeds in animal feeds (poultry), complete human diet (balance diet for elderly ones who need little carbohydrate but much protein) and an antidote for children suffering from malnutrition is recommended. The groundnut type used for this analysis was the Boro light variety.
\end{abstract}

Key words: Proximate analysis, Arachis hypogaea, Therapeutic, Antidote, Animal feeds.

\section{INTRODUCTION}

Groundnuts (Arachis hypogaea) or peanut is a legume which is widely grown as a food crop. It is an herbaceous plant of which there are different varieties such as Boro light, Boro Red, Mokwa, Campala, Guta and Ela (Anyasor, 2009).Peanut is an important source of edible oil for millions of people living in the tropics. In Nigeria, 1917 tons of peanuts are being produced annually (Ergul, 1988). Peanuts are among the oldest oil crops in Nigeria and are mostly consumed as Snack, after roasting (Bansal et al. 1993; jambunathan et al 1993). Vegetable oil had made an important contribution to the diet in many countries, serving as a good source of protein, lipid and fatty acids for human nutrition including the repair of worn out tissue, new cells formation as well as a useful source of energy(Gaydou et al. 1983;Grosso and Guzman, 1995; Grosso et al. 1997,1999).

Groundnut provides an inexpensive source of high quality dietary protein and oil. The vast food preparations incorporating groundnut to improve the protein level has helped in no small way in reducing malnutrition in the developing Countries (Asibuo et al 2008).

Groundnut seed contains 44 to $56 \%$ oil and 22 to $30 \%$ protein on a dry seed basis and is a rich source of minerals $(\mathrm{P}, \mathrm{Ca}, \mathrm{Mg}$ and $\mathrm{K})$ and Vitamins $(\mathrm{E}, \mathrm{K}$ and B group) (savage and Keenan, 1994). Groundnut protein is increasingly becoming important as food and feed sources, especially in developing Countries where protein from animal sources are not within the means of the majority of the populace. The seed has several uses as whole seed or processed to make peanut butter, oil soups, stews and other products. The cake has several uses in feed and infant food formulations. Groundnut provides considerable amounts of mineral elements to supplement the dietary requirements of humans and farm animals. (Asibuo et al 2008). Groundnut seeds are reported to contain 9.5 to $19.0 \%$ total carbohydrates as both soluble and insoluble carbohydrate (Crocker and Barton, 1957;Rao et al.1965;Oke,1967;Abel Rahman,1982;Woodroof,1983). The chemical composition of groundnut seeds have been evaluated 
in relation to protein level (Young and Hammons,1973).Good nutrition is a basic human right but in order to have a healthy population that can promote development, the relation between food, nutrition and health should be re-enforced. Knowledge of the nutrition value of local dishes, soup ingredients and local foodstuff is necessary in order to encourage the increase cultivation and consumption of this highly nutritive nut. The consumption will help to supplement the nutrients of stable carbohydrate foods of the poor who cannot afford enough protein foods of animal origin hence the objective of this study is to determine the food value of Arachi hypogeal seeds with respect to protein, fat, carbohydrate and other components. It is hoped that this would assist in its utilisation as a substitute for meat protein in our diet, to encourage the elderly ones in our midst to feed more on groundnut seeds and also as foodstuff for livestock that can in turn provide a reliable supply of protein to the people of Nigeria.

\section{MATERIALS AND METHODS.}

Sample preparation: The Arachi hypogeal (Boro variety) was bought at a local market in Ogbomoso town and transported in a polythene bag to the Laboratory. The groundnut was divided into three parts of $100 \mathrm{~g}$ each, one part was roasted, second part was sun-dried and the third part was used raw.

Proximate Analysis: The moisture, ash, crude fibre and protein contents were determined in accordance with the method described by Adeyeye (1992). Fat extraction was carried out by soxhlet extraction method according to Pearson(1981).The carbohydrate content was determined by difference, subtracting the sum of moisture, ash, protein, fat, crude fibre percentage from hundred.

\section{RESULTS AND DISCUSSION}

The proximate analysis of Arachis hypogaea seeds has been studied. The result of this research is similar to that reported by Asibuo et al (2008).

The presence of high fat content $(46.10 \%, 43.80 \%$, $40.60 \%$ ) makes it a suitable source of nutrient that can improve the energy density of man and animals.

The protein in groundnut seeds contributes to the growth and repair of worn-out tissues, will also improve the nutrition of humans and animals .

The ash content is relatively low, since the ash contains the minerals which can be estimated from it by atomic absorption spectrophotometry, it can be a good source of nutrients for consumers

The crude fibre is not high enough but can aid digestibility in humans

The carbohydrate content is slightly high, especially in the roasted groundnut, makes it a suitable source of nutrient.

The moisture content is low, this makes the shelf-life to be long and contribute to the stability of Arachis hypogeal and prevent rancidity of the oil.

Raw groundnut showed a good source of sodium, the sun-dried groundnut is a good source of magnesium and Iron while the roasted groundnut is a good source of potassium, calcium, zinc and phosphorus. The availability of calcium, magnesium, phosphorus is a good indication that the groundnut is so rich in the minerals for bone formation. Calcium is very essential in blood clothing, muscles contraction and in certain enzymes in metabolic processes.

Table 1: Proximate analysis of Arachis hypogaeal (groundnut) seeds on \% dry weight basis

\begin{tabular}{|l|l|l|l|}
\hline Compositions & Raw & $\begin{array}{l}\text { Sun- } \\
\text { dried }\end{array}$ & Roasted \\
\hline Moisture content & 7.48 & 3.40 & 1.07 \\
\hline Ash content & 1.48 & 1.38 & 1.41 \\
\hline Crude fibre & 2.83 & 2.43 & 2.41 \\
\hline Crude fat/oil & 46.10 & 43.80 & 40.60 \\
\hline Protein & 24.70 & 21.80 & 18.40 \\
\hline Carbohydrate & 17.41 & 27.19 & 36.11 \\
\hline
\end{tabular}

Results are means of three determinations

Table 2: Mineral Composition of the groundnut on dry weight basis

\begin{tabular}{|l|l|l|l|}
\hline Mineral & $\begin{array}{l}\text { Raw } \\
\text { groundnut } \\
\% \text { dry } \\
\text { weight }\end{array}$ & $\begin{array}{l}\text { Sun-dried } \\
\text { groundnut } \\
\% \text { dry } \\
\text { weight }\end{array}$ & $\begin{array}{l}\text { Roasted } \\
\text { groundnut } \\
\% \text { dry } \\
\text { weight }\end{array}$ \\
\hline Sodium $(\mathrm{Na})$ & 0.71 & 0.69 & 0.57 \\
\hline Potassium(K) & 0.47 & 0.51 & 0.55 \\
\hline Calcium $(\mathrm{Ca})$ & 1.18 & 1.24 & 1.35 \\
\hline Magnesium(Mg) & 0.18 & 0.21 & 0.24 \\
\hline Iron(Fe) & 0.40 & 0.47 & 0.47 \\
\hline Zinc(Zn) & 0.44 & 0.42 & 0.50 \\
\hline Phosphorus(P) & 0.68 & 0.65 & 0.69 \\
\hline
\end{tabular}

Results are means of three determinations

\section{CONCLUSION:}

Groundnut seeds can be use for many purposes, depending on the form or state; raw, sun-dry and roasted forms. Nutritionally, these seeds are 
advisable for human consumption because of the nutrient and mineral contents present in them. However, these seeds could also be used industrially because of the high content of oil present in the groundnut seeds.

\section{REFERENCES}

Abdel Rahman, AHY(1982).Changes in Chemical Composition of Peanut during development and ripening. Rivista Italiana Delle Sostanze Grasse 59(6):285-286.

Adeyeye,A. and Ajewole, K.(1992).Chemical Composition and Fatty acid profiles of cereals in Nigeria. Food Chem. Vol.44.pp41-44.

Anyasor,G.N., Ogunwenmo,K.O., Oyelana,O.A., Ajayi,D. and Dangana,J. (2009).Chemical Analyses of Groundnut(Arachi hypogaea)Oil. Pak. J. Nutri.8 (3):269-272.

Asibuo, J.Y, Akromah, R, Safo-Kantanka, O.O sei,AduDapaah, Hanskofi, O.S and Agyeman, A. (2008).Chemical Composition of Groundnut, Arachis hypogaea(L)landraces. African Journal of Biotechnology. Vol, 7(13),pp: 2203-2208.Website http://www.academicjournais.org/AJB

Bansal,U.K,D.R.Satija and K.L.Ahula (1993).Oil Composition of diverse groundnut(Arachi hypogaea.L) genotypes relation to different environments. J. Sci. Food Agric.63:17-19.

Crocker,W.and Barton,L.V(1957).Physiology of seed. Chronica Botanica Waltham,Massachusetts, pp.267.

Ergul,N.(1988).Peanut Production. Mediterranean Agriculture Research Institute,Ankara-Turkey, Publ. Nu.,pp.308.

Gaydou,E.M,J.P.Bianchini and J.Ratovogery,(1983). Triterpene alcohols, methyl sterols sterol and fatty acids five Malagasy legume seed oils. J.Agric.Food Chem.31:833-836.
Grosso,N.R and Guzman, C.A. (1995).Chemical Composition of Aboriginal Peanut(Arachi hypogaea.L)Seeds from Peru. J.Agric.Food Chem.43:102-105.

Grosso,N.R.,Lucini,E.I, Lopez,A.G and Guzman,C.A. (1999).Chemical Composition of Aboriginal Peanut(Arachi hypogaea.L)Seeds from Uruguay. Grasasy Aceites,50:203-207.

Grosso,N.R.,Zygadlo,J.A.,Lamarque,A.L., Maestri,D.M. and Guzman,C.A. (1997).Proximate, Fatty acid and sterol Compositions of Aboriginal Peanut(Arachi hypogaea.L)Seeds from Bolivia. J.Sci.Food Agric.73:249-356.

International Institute of Tropical Agriculture(1989).The Cowpea,Biotechnology and Natural Pest Control. IITA Research Briefs,9,5-6.

Jambunathan,R.Raju,S.M.and Barde,S.P.(1985).Analysis of Groundnut Content by Nuclear Magnetic Resonance Spectrometry. J.Sci.Food Agric.36:162-166.

Oke, O.L. (1967).Chemical Studies on Some Nigerian Pulses. West Africa J.Bio.Appl.Chem.9:52-55.

Pearson,D.(1981).The Chemical Analysis of Food.( $8^{\text {th }}$ Ed.). J.A.Churchill, London,pp:535.

Rao,S.K. Rao, SDT ,and Murti, K.S. (1965).Compositional Studies on India Groundnut-111. India Oilseed J.9:513.

Savage,G.P,and Keenan,J.I(1994).The Composition and Nutritive Value of Groundnut Kernels. In: Smart $\mathrm{J}(\mathrm{ed})$.The Groundnut Crop: Scientific basis for improvement. London: Chapman and Hall, pp.173213.

Woodroof ,J. G (1983).Peanuts Production, Processing, Products. 3th ed. Avi Publishing Company Inc. Westport, Connecticut.

Young, C.T, Waller, G. R, and Hammons ,R.O. (1973).Variations in total amino acid of peanut meal. J. Am. Oil Chem. Soc. 50:521-523. 